DOI: 10.2478/awutp-2020-0002

Vol. LXII, 2020

\title{
STUDY THE EFFECT OF Cu DOPING ON OPTICAL AND STRUCTURAL PROPERTIES OF NiO THIN FILMS
}

\author{
Said Benramache ${ }^{1, *}$, Boubaker Benhaoua ${ }^{2}$, Hanane Guezzoun ${ }^{3}$ \\ ${ }^{1}$ Material Sciences Department, Faculty of Science, University of Biskra 07000, Algeria, \\ s.benramache@univ-biskra.dz \\ ${ }^{2}$ Renewable Energy Research Unit in Arid Zones, University of El-Oued, 39000, Algeria. \\ benhaouab@yahoo.3com \\ ${ }^{3}$ Department of Physics, University of El-Oued, 39000, Algeria. guezzounhanane@yahoo.fr
}

\begin{tabular}{|c|c|}
\hline Article Info & Abstract \\
\hline $\begin{array}{lr}\text { Received: } & 10.01 .2020 \\
\text { Accepted: } & 07.04 .2020 \\
& \\
\text { Keywords: } & \mathrm{Cu}, \mathrm{NiO}, \\
\text { Thin films, Spain coater } \\
\text { method, polycrystalline } \\
\begin{array}{l}\text { structure, } \\
\text { conductivity. }\end{array}\end{array}$ & $\begin{array}{l}\text { In this work, copper doped nickel oxide as the thin films have been } \\
\text { elaborated by a spin coating method, the nickel chloride hexahydrate }(0.8 \mathrm{M}) \text { and } \\
\text { copper (II) chloride dehydrate }(\mathrm{Cu} / \mathrm{Ni}=0,2.15,4.3,8.6 \text { and } 12.9 \mathrm{At} . \%) \text { were used } \\
\text { to prepare the } \mathrm{Cu} \text { doped } \mathrm{NiO} \text { thin films. The } \mathrm{Cu} \text { doped } \mathrm{NiO} \text { thin films were heated } \\
\text { at a crystallization temperature of } 600^{\circ} \mathrm{C} \text { with } 2 \mathrm{~h} \text {. The obtained thin films by spin } \\
\text { coater method have a film thickness in the order of } 400 \mathrm{~nm} \text {. The prepared } \mathrm{Cu} \\
\text { doped } \mathrm{NiO} \text { thin films have a polycrystalline with cubic structure }(200) \text { peak was } \\
\text { observed. The optical property shows that the prepared thin films have a } \\
\text { transmittance of about } 70 \% \text {. The } \mathrm{Cu} \text { doped NiO thin films have minimum bandgap } \\
\text { energy is } 3.85 \mathrm{eV} \text { at } 12.9 \text { at. } \% \text {, the thin film deposited at } 8.6 \text { at. } \% \text { has the highest } \\
\text { value of Urbach energy is } 425 \mathrm{meV} \text {. The } \mathrm{Cu} \text { doped } \mathrm{NiO} \text { thin films have a high } \\
\text { electrical conductivity of } 8.6 \text { at } \% \text { it is } 7(\Omega . \mathrm{cm})^{-1} \text {. The prepared } \mathrm{Cu} \text { doped NiO thin } \\
\text { film was suitable for gas sensing applications due to the existing phase and higher } \\
\text { electrical conductivity. }\end{array}$ \\
\hline
\end{tabular}

\section{Introduction}

In the latest research, for the important subjects, in the field of materials science, the synthesis of thin films from a metal oxide (semiconductor) that was used as a gas sensor. The Nickel oxide was found a belongs to a class of the semiconductor materials, it was found in the cubic structure, and has a good transparent in the thin film. NiO was used in sciences and technology as the optoelectronic field due to the good structure crystallinity and the best transmittance was obtained at the longer wavelength smaller than the $400 \mathrm{~nm}$. The bandgap energy of $\mathrm{NiO}$ thin films varied between 3.6 to $4 \mathrm{eV}$. However, the thin films of $\mathrm{NiO}$ can be used in various applications due to the simplicity of synthesis such as solar cells, chemical 
sensors, photodetectors, electrochromic minors, organic light-emitting diodes, UV detectors, vans parent diodes, and defrosting windows [1-6].

The thin films of $\mathrm{NiO}$ can be obtained by various deposition methods likely electrochemical deposition, pulsed laser deposition, magnetron sputtering, molecular beam epitaxy (MBE), reactive evaporation, sol-gel process, chemical vapor deposition, and spray pyrolysis [7-9]. NiO has been intensively studied as a promising material for gas sensors in the detection due to the range of wide bandgap (3.6-4.0 eV) and high stability that are similar to $\mathrm{ZnO}[10,11]$.

The aim of this work is to obtain a thin film with good physical properties for gas sensing applications, which can be obtained through the largest absorption values, and this indicates a decrease in the optical band gap energy. In the past research, the literature was investigated the $\mathrm{NiO}$ thin film as detection in the environment for various gases such as $\mathrm{CO}$, $\mathrm{CO}_{2}, \mathrm{SO}_{2}, \mathrm{NO}_{2}, \mathrm{CH}_{4}$. However, we have prepared the $\mathrm{Cu}$ doped $\mathrm{NiO}$ thin films for furthers application in gas sensing due to the corporation of the $\mathrm{Cu}$ with $\mathrm{Ni}$ in increasing the electrical conductivity. The spin coating method has been used in this work to fabricated the thin films of $\mathrm{Cu}$ doped $\mathrm{NiO}$, these thin films were fabricated on a substrate of microscope glass. The films were prepared with $0.8 \mathrm{M}$ at a crystallization temperature of $600{ }^{\circ} \mathrm{C}$. The influence of $\mathrm{Cu}$ concentration on optical, structural and electrical characterizations of $\mathrm{Cu}$ doped $\mathrm{NiO}$ has been studied.

\section{Experiments}

\subsection{Solution preparation}

The prepared solutions $\mathrm{Cu}$ doped $\mathrm{NiO}$ have been dissolved of $0.8 \mathrm{M}$ of the nickel chloride hexahydrate $\mathrm{NiCl}_{2} \cdot 6 \mathrm{H}_{2} \mathrm{O}$ in the absolute $\mathrm{H}_{2} \mathrm{O}, \mathrm{HCl}$ was used as a stabilization solution of $\mathrm{NiO}$, and the copper(II) chloride dehydrate $\mathrm{CuCl}_{2} \cdot 2 \mathrm{H}_{2} \mathrm{O}$ was used to prepare the $\mathrm{CuO}$ solution. The final mixture solution of $(\mathrm{Cu} / \mathrm{Ni})=0,2.15,4.3,8.6$ and 12.9 At.\% were stirred a heated at $40{ }^{\circ} \mathrm{C}$ to have a solution with high transparency. The film coating was deposited two days after the preparation.

\subsection{Thin films preparation}

The $\mathrm{Cu}$ doped $\mathrm{NiO}$ samples have been elaborated by dropping the $\mathrm{Cu}$ doped $\mathrm{NiO}$ solution on a glass substrate at room temperature by a spin coating method, which has been the speed of rotating confined between 2500 to $3000 \mathrm{rpm}$ for $45 \mathrm{~s}$, which it is repeated 20 times. The $\mathrm{Cu}$ doped $\mathrm{NiO}$ thin films have been elaborated at several $\mathrm{Cu}$ concentrations are 0 , 
2.15, 4.3, 8.6 and 12.9 At.\%. The thin films become heated at a temperature of $200{ }^{\circ} \mathrm{C}$, and then annealed for the crystallization of the $\mathrm{Cu}$ doped $\mathrm{NiO}$ thin films at $600{ }^{\circ} \mathrm{C}$ in air for $2 \mathrm{~h}$. Table 1 shows the experimental conditions such as the concentration of $\mathrm{Cu}$, deposition rate, deposition time, the annealing temperature and the final measured film thickness of $\mathrm{Cu}$ doped $\mathrm{NiO}$ thin films. The final $\mathrm{Cu}$ doped $\mathrm{NiO}$ thin films were stayed for one to three weeks after deposition to characterize.

Table 1. The experimental conditions of deposition $\mathrm{Cu}$ doped NiO by spin coating method.

\begin{tabular}{|c|c|c|c|c|c|}
\hline $\begin{array}{l}\text { Sample } \\
\text { number }\end{array}$ & $\begin{array}{l}\text { Cu concentrations } \\
(\text { At. } \%)\end{array}$ & $\begin{array}{c}\text { Deposition } \\
\text { rate }(\mathrm{ml})\end{array}$ & $\begin{array}{l}\text { Deposition } \\
\text { time }(\mathrm{s})\end{array}$ & $\begin{array}{l}\text { Annealing } \\
\text { temperature }\left({ }^{\circ} \mathrm{C}\right)\end{array}$ & $\begin{array}{l}\text { Final film } \\
\text { thickness (nm) }\end{array}$ \\
\hline 1 & 0 & 3 & 45 & 600 & 390 \\
\hline 2 & 2.15 & 3 & 45 & 600 & 450 \\
\hline 3 & 4.3 & 3 & 45 & 600 & 420 \\
\hline 4 & 8.6 & 3 & 45 & 600 & 430 \\
\hline 5 & 12.9 & 3 & 45 & 600 & 380 \\
\hline
\end{tabular}

\subsection{Thin films characterization}

The $\mathrm{Cu}$ doped $\mathrm{NiO}$ thin films have been characterized in order to get the physical properties such as optical, structural and electrical. The optical transmittance of fabricated $\mathrm{Cu}$ doped NiO films was measured by a UV-visible (35-LAMBDA) in the range of 300-1000 $\mathrm{nm}$. The crystalline structure of fabricated films were obtained by X-ray diffraction (Bruker$\mathrm{XRD} \mathrm{AXS}-8 \mathrm{D}, \lambda \mathrm{CuK} \alpha=0.15406 \mathrm{~nm}$ with $2 \theta$ varying between $30^{\circ}$ and $50^{\circ}$ ). And the electrical conductivity was measured by injection current-voltage by four-point method into the deposited film surface. All characterizations have been made at stable conditions.

\section{Results and discussion}

In Fig. 1, the variation of optical transmittance of elaborated $\mathrm{Cu}$ doped $\mathrm{NiO}$ thin films have been presented as a function of the longer of the wavelength in the range of 300-1000 nm. As seen from these spectra's the transmittance of $\mathrm{Cu}$ doped $\mathrm{NiO}$ thin films were decreased with increasing $\mathrm{Cu}$ concentration in the visible region, the maximum transmittance of $\mathrm{Cu}$ doped $\mathrm{NiO}$ thin films were obtained for $0,2.15$ and 4.3 at.\%, it is $70 \%$ caused by the interstitial site of $\mathrm{Cu}$ and $\mathrm{Ni}$. The transmission of $\mathrm{Cu}$ doped $\mathrm{NiO}$ thin films at higher 
concentrations in the visible region was decreased due to the increase in absorption. When the absorption condition was satisfied, the detection was beginning and the gas concentration, which was comparable at a higher concentration of $\mathrm{Cu}$. The band gap energy of fabricated thin films of $\mathrm{Cu}$ doped $\mathrm{NiO}$ have been derived from the direct transitions of inter-band in the valence band and conduction band, it was determined by following equation [12]:

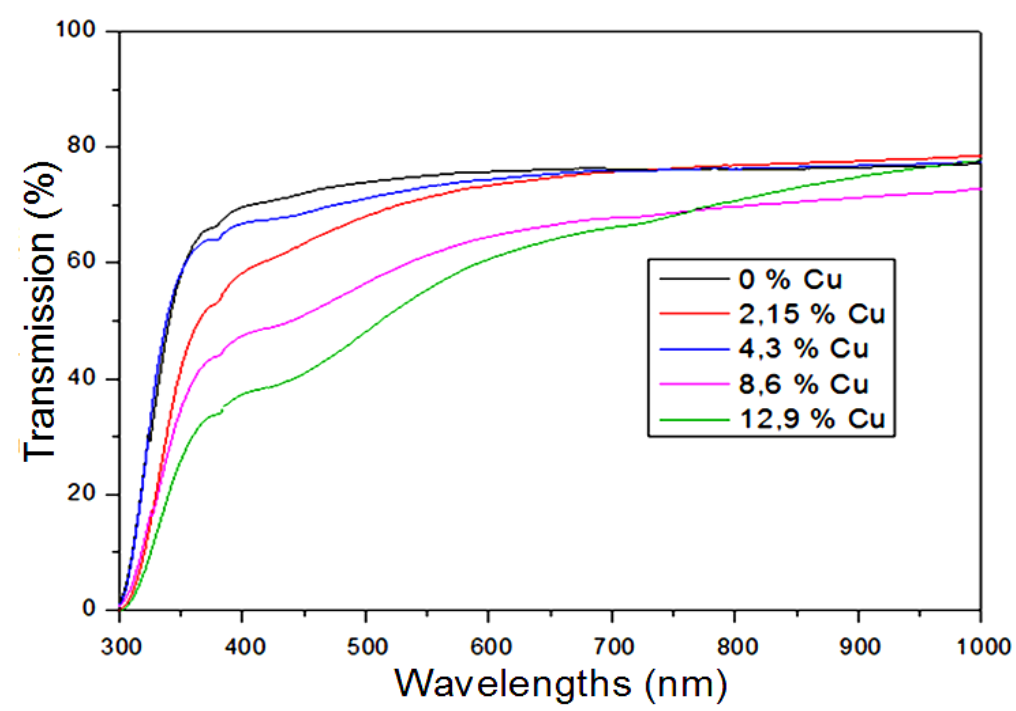

Figure 1. The variation of optical transmittance $(T)$ as a function of longer of the wavelength $(\lambda)$ of fabricated $\mathrm{Cu}$ doped $\mathrm{NiO}$ thin film deposited at several $\mathrm{Cu}$ concentrations.

$$
(A h v)^{2}=B\left(h v-E_{g}\right)
$$

where $A, h v \quad C$ and $E_{g}$ are the absorbance, the energy of the photon, a constant and the band gap energy of $\mathrm{Cu}$ doped $\mathrm{NiO}$ thin films, respectively. However, the tail width can be calculated using the Urbach energy for the absorption coefficient at lower photon energy [13]:

$$
A=A_{0} \exp \left(\frac{h v}{E_{u}}\right)
$$

where $A, h v, A_{0}$ and $E_{u}$ are the absorbance, the energy of the photon, a constant and the Urbach energy, respectively. The Urbach energy has been determined by deducing the curves of the variation of $L n A$ with the photon energy $h v$ to obtain of Urbach energy values of $\mathrm{Cu}$ doped $\mathrm{NiO}$ thin films.

Fig. 2 shows the variation of the band gap energy and the Urbach energy of fabricated $\mathrm{Cu}$ doped $\mathrm{NiO}$ thin films at several $\mathrm{Cu}$ concentrations. As seen, the band gap energy 
decreased with increasing of $\mathrm{Cu}$ concentration to the highest value of $3.85 \mathrm{eV}$ was obtained with 12.9 at.\% $\mathrm{Cu}$ (see Table 2), this decrease can be explained by the corporation between $\mathrm{Ni}$ and $\mathrm{Cu}$ in the interstitial site, which was showed for the oxygen vacancy. However, the Urbach energy was increased from $325 \mathrm{meV}$ for 0 at.\% to $425 \mathrm{meV}$ for 8.6 at.\% (see Table 2), and then decreased to $395 \mathrm{meV}$ for 12.9 at.\%, the decrease of Urbach energy of $\mathrm{Cu}$ doped $\mathrm{NiO}$ thin films can be linked by the decrease of the defects in the film network and the increase can be related the reduction of absorption, which is shown for the higher transmittance of fabricated $\mathrm{Cu}$ doped $\mathrm{NiO}$ thin films for the lowest concentration.

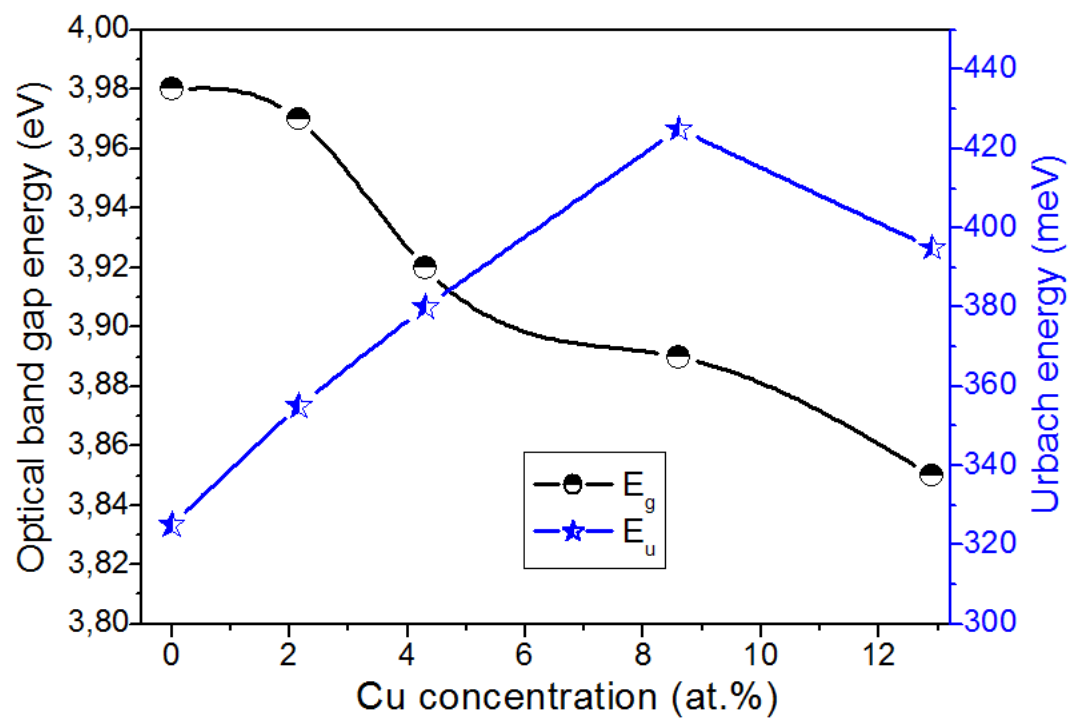

Figure 2. The variation of bandgap energy and Urbach energy of fabricated $\mathrm{Cu}$ doped NiO thin films at several $\mathrm{Cu}$ concentrations.

Table 2. The variation of the band gap energy and the Urbach energy of $\mathrm{Cu}$ doped $\mathrm{NiO}$ thin films at different $\mathrm{Cu}$ concentrations.

\begin{tabular}{|c|c|c|c|}
\hline Cu concentration (at.\%) & $\begin{array}{l}\text { Optical band gap } \\
\text { energy } E_{\mathrm{g}}(\mathrm{eV})\end{array}$ & $\begin{array}{l}\text { Urbach energy } \mathrm{E}_{\mathrm{u}} \\
(\mathrm{meV})\end{array}$ & $\begin{array}{l}\text { Film thickness d } \\
(\mathrm{nm})\end{array}$ \\
\hline 0 & 3.98 & 325 & 390 \\
\hline 2.15 & 3.97 & 355 & 450 \\
\hline 4.3 & 3.92 & 380 & 420 \\
\hline 8.6 & 3.89 & 425 & 430 \\
\hline 12.9 & 3.85 & 395 & 380 \\
\hline
\end{tabular}

The crystalline structure of $\mathrm{Cu}$ doped $\mathrm{NiO}$ thin films is detected in Fig. 3, it is presented the X-ray diffraction variation in the range of $2 \theta=30^{\circ}$ to $50^{\circ}$. The $\mathrm{NiO}$ thin film prepared at 
0 at\% $\mathrm{Cu}$ presented tow diffraction peaks were (111) and (200) peak. After doping, we have observed only one diffraction peak at $2 \theta=43.5^{\circ}$, it is (200) peak of $\mathrm{NiO}$ cubic structure in nature, which it fined that the elaborated $\mathrm{Cu}$ doped $\mathrm{NiO}$ thin films have a polycrystalline structure with (200) plan. This attribution was detected that the $\mathrm{Cu}$ doped $\mathrm{NiO}$ thin films have been preferred to (200) plan. This material was suitable for gas sensing applications due to the existing phase and can change the transfer of the free electron.

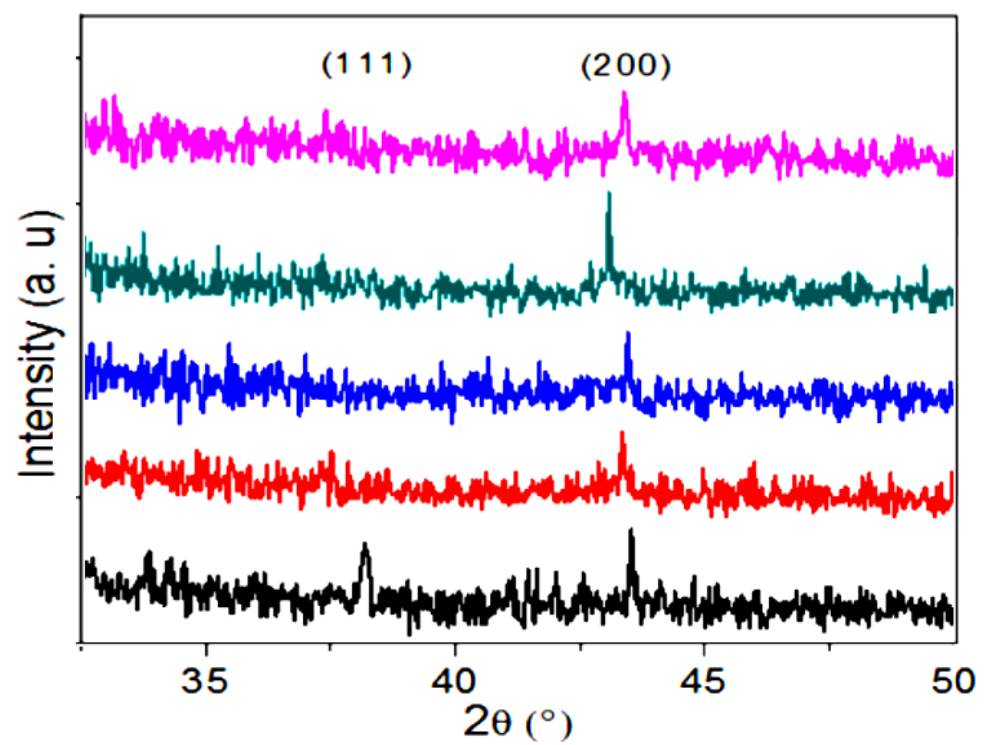

Figure. 3. XRD spectra of fabricated thin films of $\mathrm{Cu}$ doped $\mathrm{NiO}$ deposited at several $\mathrm{Cu}$ concentrations.

The electrical conductivity $\sigma$ of $\mathrm{Cu}$ doped $\mathrm{NiO}$ thin films was determined by fourpoints probe method, it is based on measured the sheet resistance $R_{s h}$ of the films as expressed by:

$$
\begin{gathered}
R_{s h}=\frac{\pi}{\ln (2)} \cdot \frac{V}{I} \\
\sigma=\frac{1}{\rho}=\frac{1}{d R_{s h}}
\end{gathered}
$$

where $\rho$ is the electrical resistivity, $d$ is the film thickness, $I$ is the applied currant $=1 \mathrm{nA}$ and $V$ is the measurement voltage (see Table 3 ).

The electrical conductivity of fabricated $\mathrm{Cu}$ doped $\mathrm{NiO}$ thin films is placed in Fig. 4 and Table 3, as seen, the electrical conductivity was increased from $2.1(\Omega . \mathrm{cm})^{-1}$ for 0 at.\% to $7(\Omega . \mathrm{cm})$ for 8.6 at.\% (see Table 1$)$, and then decreased to $3.5(\Omega . \mathrm{cm})^{-1}$ for 12.9 at.\%, it is 
comparable with the variation of tail energy (see Fig. 2). The decrease of electrical conductivity of $\mathrm{Cu}$ doped $\mathrm{NiO}$ thin films caused by the oxygen vacancy and the increase can be linked by the oxygen diffusion. The increase of electrical conductivity of $\mathrm{Cu}$ doped $\mathrm{NiO}$ thin films can be to the increases sensor time of gas detection.

Table 3. The electrical characterizations of $\mathrm{Cu}$ doped $\mathrm{NiO}$ thin films at different $\mathrm{Cu}$ concentrations.

\begin{tabular}{|c|c|c|c|}
\hline Cu concentration (at.\%) & $\begin{array}{l}\text { Sheet resistance } \\
R_{s h}(\Omega)\end{array}$ & $\begin{array}{c}\text { Electrical conductivity } \\
\sigma\left(\Omega . \mathrm{cm}^{-1}\right.\end{array}$ & $\begin{array}{l}\text { Film thickness d } \\
(\mathrm{nm})\end{array}$ \\
\hline 0 & 12210.2 & 2.1 & 390 \\
\hline 2.15 & 6944.4 & 3.2 & 450 \\
\hline 4.3 & 5291.1 & 4.5 & 420 \\
\hline 8.6 & 3322.2 & 7 & 430 \\
\hline 12.9 & 7518.8 & 3.5 & 380 \\
\hline
\end{tabular}

a. Optical band gap energy

b. Urbach energy

c. Film thickness

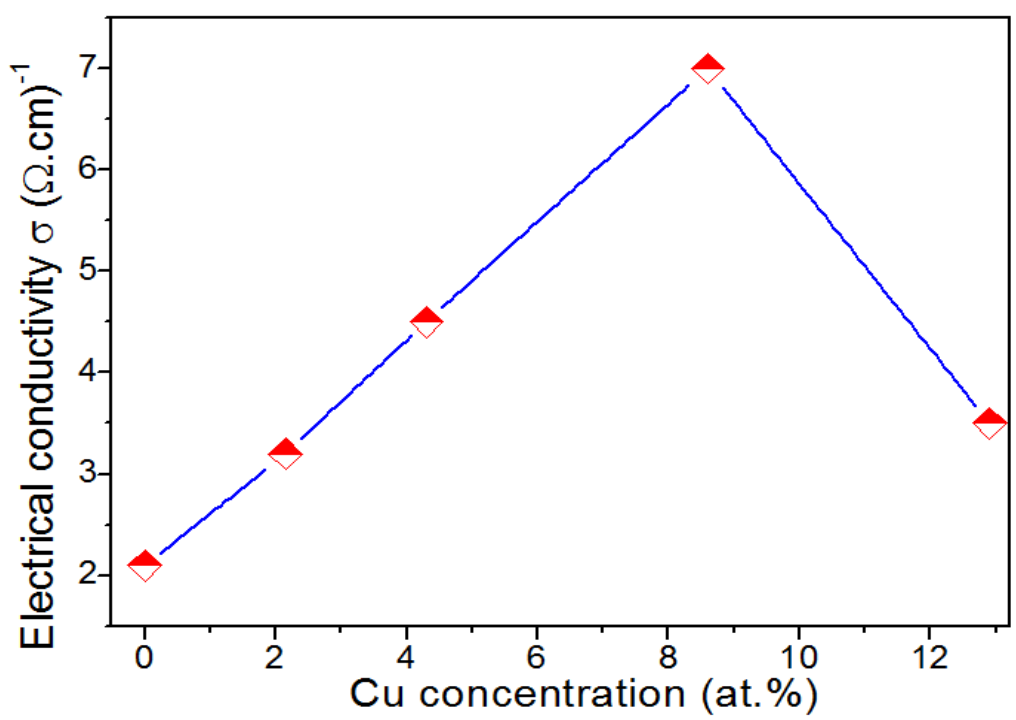

Figure 4. The electrical conductivity of fabricated $\mathrm{Cu}$ doped $\mathrm{NiO}$ thin films at different $\mathrm{Cu}$ concentrations.

\section{Conclusions}

In this work, nickel oxide doping with copper $(\mathrm{Cu}$ doped $\mathrm{NiO})$, where $(\mathrm{Cu} / \mathrm{Ni})=0$, 2.15, 4.3, 8.6 and 12.9 At.\% were successfully elaborated on a glass substrate by spin coating method with $0.8 \mathrm{M}$ using nickel chloride hexahydrate and the ration of copper(II) chloride dehydrate. The $\mathrm{Cu}$ doped $\mathrm{NiO}$ thin films have been heated at a crystallization temperature of $600{ }^{\circ} \mathrm{C}$ for $2 \mathrm{~h}$. The obtained thin films by spin coater method have a film thickness in the 
order of $400 \mathrm{~nm} . \mathrm{Cu}$ doped $\mathrm{NiO}$ thin films were observed a polycrystalline a cubic structure (200) peak was observed. All prepared thin films have an average transmittance is approx. 70 $\%$ in the region of visible. The decrease in the transmission of $\mathrm{Cu}$ doped $\mathrm{NiO}$ thin films at a higher concentration due to the increase in absorption, which it indicated to begin the gas detection such as the example of our work. The $\mathrm{Cu}$ doped $\mathrm{NiO}$ thin films have minimum band gap energy is $3.85 \mathrm{eV}$ at 12.9 at.\%, the thin film deposited at 8.6 at.\% has the highest value of Urbach energy is $425 \mathrm{meV}$. The $\mathrm{Cu}$ doped $\mathrm{NiO}$ thin films prepared 8.6 at\% has the highest electrical conductivity is $7(\Omega . \mathrm{cm})^{-1}$. The increase of electrical conductivity of $\mathrm{Cu}$ doped $\mathrm{NiO}$ thin films can be to the increases sensor time of gas detection. The prepared $\mathrm{Cu}$ doped $\mathrm{NiO}$ thin film was suitable for gas sensing applications due to the existing phase and higher electrical conductivity.

\section{References}

[1] R. Sharma, A.D. Acharya and S.B. Shrivastava, et al. Optik 127(2016) 4661-4668.

[2] R. Sharma, A.D. Acharya and S.B. Shrivastava, et al. Optik 125(2014) 6751-6756.

[3] K. Sajilal and A. Moses Ezhil Raj, Optik 127(2016) 1442-1449.

[4] D. Dini, Y. Halpin, J.G. Vos and E.A. Gibson, Coordination Chemistry Reviews 304305(2015) 179-201.

[5] G.F. Cai, C.D. Gu and J. Zhang, et al. Electrochimica Acta 87(2013) 341-347.

[6] A.C. Nwanya, S.U. Offiah and I.C. Amaechi, et al. Electrochimica Acta 171(2015) 128141.

[7] T. Chtouki, L. Soumahoro and B. Kulyk, et al. Optik 128(2017) 8-13.

[8] W. Yan and W. Weng, et al. Applied Physics Letters 92(2008) 052508.

[9] X. Chen, L. Zhao and Q. Niu, Journal of Electronics Materials 41(2012) 382-3386.

[10] Y. Aoun, M. Marrakchi and S. Benramache, et al. Materials Research 21(2018) e20170681.

[11] S. Benramache and B. Benhaoua, Superlattices and Microstructures 52 (2012) 807-815.

[12] S. Benramache and B. Benhaoua, Superlattices and Microstructures 52(2012) 10621070.

[13] S. Benramache, O. Belahssen, H. Ben Temam, International Journal of Renewable Energy Research 4 (2014) 1009-1012.

[14] S. Benramache, Y. Aoun, A. Charef, B. Benhaoua, S. Lakel, Inorganic and Nano-Metal Chemistry 49 (2019) 177-181. 